\title{
Penerapan Metode Problem Solving dalam Meningkatan Hasil Belajar PPKn
}

\author{
Andriana ${ }^{1}$, Nunung Nugrahawati ${ }^{2}$, Huriah Rachmah ${ }^{3}$ \\ ${ }^{1}$ Sekolah Menengah Pertama Negeri 1 Pabuaran Subang \\ ${ }^{2}$ Sekolah Dasar Negeri 4 Ciharashas Bandung Barat \\ ${ }^{3}$ STKIP Pasundan Cimahi \\ 1'andriana100481@gmail.com
}

\begin{abstract}
ABSTRAK
Penelitian ini adalah penelitian tindakan kelas yang bertujuan untuk meningkatkan hasil belajar siswa dengan penggunaan metode problem solving pada pembelajaran PPKn di kelas VIII E SMP Negeri 1 Pabuaran Subang. Subjek penelitian ini adalah siswa kelas VIII E yang berjumlah 40 orang siswa, yang terdiri dari 21 orang laki-laki dan 19 orang perempuan. Penelitian tindakan kelas ini dilaksanakan dalam dua siklus dan setiap siklus terdiri dari empat tahapan yaitu: perencanaan, pelaksanaan tindakan, observasi/evaluasi dan refleksi. Analisis data yang digunakan yaitu menggunakan pendekatan deskriptif kuantitatif. Hasil penelitian menunjukkan bahwa pembelajaran PPKn dengan penggunaan metode problem solving pada pada siswa kelas VIII E SMP Negeri 1 Pabuaran dapat meningkatkan hasil belajar siswa. Hasil belajar siswa pada siklus I adalah rata-rata 74,98 ada di bawah KKM yang ditetapkan sekolah dengan nilai 75. Sedangkan hasil belajar pada siklus II sebesar 80,03 ada di atas KKM. Jadi hasil belajar siswa SMP Negeri 1 Pabuaran Subang dengan metode problem solving dari siklus I sampai dengan siklus II mengalami peningkatan
\end{abstract}

Kata kunci: Metode problem solving, hasil belajar, Pendidikan Pancasila dan kewarganegaraan

\section{PENDAHULUAN}

Pada kehidupan yang modern dan serba canggih seperti saat ini, pendidikan memegang peranan penting untuk menjamin kelangsungan hidup. Pendidikan merupakan wahana untuk meningkatkan dan mengembangkan kualitas sumber daya manusia. Melalui penyelenggaraan pendidikan diharapkan dapat mencetak manusia-manusia berkualitas yang akan mendukung tercapainya sasaran pembangunan nasional. Dalam pasal 20 UU tahun 2003, pendidikan nasional berfungsi untuk mengembangkan kemampuan dan membentuk watak serta peradaban bangsa dengan tujuan untuk mengembangkan potensi yang dimiliki peserta didik agar menjadi manusia yang berkualitas dengan ciri-ciri beriman dan bertaqwa kepada Tuhan YME, berakhlak mulia, sehat, beriman, cakap, kreatif, mandiri, dan menjadi warga negara yang demokratis, serta bertanggung jawab.

Dalam mencapai tujuan pendidikan ini, pemerintah menggagas diberlakukannya kurikulum baru yaitu kurikulum 2013.
Pengembangan Kurikulum 2013 merupakan langkah lanjutan Pengembangan Kurikulum Berbasis Kompetensi yang telah dirintis pada tahun 2004 dan KTSP 2006 yang mencakup kompetensi sikap, pengetahuan, dan keterampilan secara terpadu. Kurikulum 2013 dikembangkan berbasis pada kompetensi sangat diperlukan sebagai instrument untuk mengarahkan peserta didik menjadi: (1) manusia berkualitas yang mampu dan proaktif menjawab tantangan zaman yang selalu berubah; (2) manusia terdidik yang beriman dan bertakwa kepada Tuhan Yang Maha Esa, berakhlak mulia, sehat, berilmu, cakap, kreatif, mandiri; dan (3) warganegara yang demokratis, bertanggung jawab. (Kemdikbud, 2014, p. 4)

Seorang pendidik harus mampu memahami makna pendidikan dan mengaplikasikannya dalam dunia pendidikan. Kemampuan peserta didik dalam proses belajar mengajar mempengaruhi tujuan dan hasil belajar peserta didik. Sehingga model pembelajaran yang digunakan juga harus mengacu pada standar 
kompetensi yang mencakup ranah kognitif, afektif, dan psikomotorik. (Kojong, 2017)

Hasil belajar mengajar dikelas mempunyai tujuan yang bersifat transaksional, artinya diketahui secara jelas oleh guru dan peserta didik. Tujuan tercapai jika peserta didik memperoleh hasil belajar seperti yang diharapkan di dalam proses pembelajaran. Hasil belajar merupakan gambaran tingkat penguasaan peserta didik terhadap sasaran belajar pada topik bahasan yang dipelajari, kemudian diukur dengan berdasarkan jumlah skor jawaban benar pada soal yang disusun sesuai dengan sasaran belajar. Hasil belajar menurut Nawari (Placeholder1p. 5), diartikan sebagai tingkat keberhasilan peserta didik dalam mempelajari materi pelajaran di sekolah yang dinyatakan dalam skor yang diperoleh dari hasil tes mengenal sejumlah materi pelajaran tertentu. Keberhasilan peserta didik dalam belajar dipengaruhi oleh faktor dari dalam diri peserta didik maupun faktor dari luar diri peserta didik. Berkenaan dengan ini menurut Wasliman (Susanto, Teori Belajar \& Pembelajaran di Sekolah Dasar, 2013, p. 13) hasil belajar yang dicapai oleh peserta didik merupakan hasil interaksi Antara berbagai faktor yang mempengaruhi, baik faktor internal maupun eksternal.

Masih rendahnya hasil belajar Pendidikan Pancasila dan Kewarganegaraan (PPKn) disebabkan oleh masih dominannya skill menghafal dari pada skill memproses sendiri pemahaman suatu materi. Selama ini, minat belajar peserta didik terhadap mata pelajaran PPKn masih tergolong sangat rendah. Hal ini dapat dilihat pada sikap peserta didik selama mengikuti proses pembelajaran tidak focus dan ramai sendiri. Bahkan ada sebagian peserta didik yang menganggap mata pelajaran PPKn tidak begitu penting dikarenakan tidak masuk pada mata pelajaran yang diujikan pada Ujian Nasional (UN). Faktor minat itu juga dipengaruhi oleh adanya metode mengajar yang digunakan guru dalam menyampaikan materi. Metode yang konvensional seperti menjelaskan materi secara abstrak, hafalan materi dan ceramah dengan komunikasi satu arah, yang aktif masih didominasi oleh pengajar, sedangkan peserta didik biasanya hanya memfokuskan penglihatan dan pendengaran. Kondisi pembelajaran seperti inilah yang mengakibatkan peserta didik kurang aktif dan pembelajaran yang dilakukan kurang efektif. Disini guru dituntut untuk pandai menciptakan suasana pembelajaran yang menyenangkan bagi peserta didik sehingga peserta didik kembali berminat mengikuti kegiatan belajar.

Setiap proses belajar dan mengajar ditandai dengan adanya beberapa unsur Antara lain tujuan, bahan, alat, dan metode, serta evaluasi. Unsur metode dan alat merupakan unsur yang tidak bias dilepaskan dari unsur lainnya yang berfungsi sebagai cara atau teknik untuk mengantarkan bahan pelajaran agar sampai kepada tujuan. Dalam pencapaian tujuan tersebut, metode pembelajaran sangat penting sebab dengan adanya metode pembelajaran, bahan dapat dengan mudah dipahami oleh peserta didik. (Putra, Putra, \& Suara, 2014)

Selain itu penggunaan metode pembelajaran yang mengajarkan peserta didik dalam pemecahan masalah, terutama pemecahan masalah dalam kehidupan sehari- hari masih kurang. Pengembangan metode pembelajaran tersebut sangat perlu dilakukan untuk menjawab kebutuhan keterampilan pemecahan permasalahan yang harus dimiliki oleh peserta didik. Metode pembelajaran problem solving atau pemecahan masalah kegunaannya adalah untuk merangsang berfikir dalam situasi masalah yang komplek. Dalam hal ini akan menjawab permasalahan yang menganggap sekolah kurang bias bermakna dalam kehidupan nyata di masyarakat.

Penggunaan metode dalam pembelajaran sangat diutamakan guna menimbulkan gairah belajar, motivasi belajar, merangsang peserta didik berperan aktif dalam proses pembelajaran. Melalui metode problem solving diharapkan dapat lebih mempermudah pemahaman materi pelajaran yang diberikan dan nantinya dapat mempertinggi kualitas proses pembelajaran yang selanjutnya dapat meningkatkan hasil belajar peserta didik. 


\section{METODE PENELITIAN}

Bentuk penelitian yang digunakan dalam penelitian ini adalah Penelitian Tindakan Kelas (Classroom Action Research) kolaborasi. Penelitian tindakan kelas ini dilaksanakan di kelas VIII E SMP Negeri 1 Pabuaran pada bulan April - Mei 2018. Subjek Penelitian ini adalah peserta didik kelas VIII E SMP Negeri I Pabuaran Subang dengan jumlah 40 peserta didik.

Proses tindakan yang dilakukan dalam penelitian tindakan kelas ini dapat dijelaskan Sebagaiberikut: a) Tahap Perencanaan, pada tahap ini dimulai dari mengajukan surat ijin observasi kepada kepala sekolah. Kemudian peneliti bekerjasama dengan guru Mapel PPKn menemukan masalah dan kemudian merancang tindakan yang dilakukan; b) Tahap Pelaksanaan Tindakan, tahap kedua penelitian ini adalah implementasi dari perencanaan yang sudah dibuat. Kegiatan guru pada tahap ini yaitu melaksanakan pembelajaran sesuai dengan RPP yang telah direncanakan dalam beberapa siklus; c) Tahap Pengamatan, tahap ketiga penelitian adalah observasi, yaitu pelaksanaan pengamatan oleh peneliti. Peneliti melakukan pengamatan ketika tindakan berlangsung, mencatat apa yang terjadi dalam proses pembelajaran agar memperoleh data yang akurat serta hasil dari kegiatan pengamatan dapat dijadikan masukan ketika guru melakukan refleksi untuk penyusunan rencana ulang untuk memasuki siklus berikutnya; d) TahapRefleksi, kegiatan yang dilakukan pada saat refleksi adalah melakukan analisis, dan mengevaluasi atau mendiskudikan data yang diperoleh selama proses pelaksanaan. Jika belum sesuai dengan indikator dan hasil yang diinginkan, maka peneliti melanjutkan siklus berikutnya sehingga dapat mencapai hasil optimal dalam rangka meningkatkan hasil belajar PPKn.

Pengumpulan data dalam penelitian ini dilakukan dengan, observasi, tes, dan dokumentasi. Observasi dilakukan dengan menggunakan lembar observasi guru, tes digunakan untuk menilai dan mengukur hasil belajar peserta didik, terutama hasil kognitif berkenaan dengan penguasaan bahan pengajaran sesuai dengan tujuan pendidikan dan pengajaran. Sedangkan dokumentasi terkait dengan penelitian berserta pengambilan foto saat kegiatan pembelajaran berlangsung. Pengumpulan data yang dilakukan dalam peneliti yaitu data kualitatif dan kuantitaitif. Dalam penelitian ini, peneliti menganalisis tes hasil belajar.

\section{HASIL PENELITIAN DAN PEMBAHASAN Hasil Penelitian}

Data awal yang diperoleh peneliti adalah melakukan penelitian dengan menggunakan hasil tes. Data tersebut digunakan sebagai patokan awal sebelum dilakukan tindakan. Adapun data awal sebelum tindakan dapat dilihat pada Tabel 1 berikut ini:

Tabel 1. Data Awal Pra Siklus

\begin{tabular}{clc}
\hline No & \multicolumn{1}{c}{ Nama } & Nilai \\
\hline 1 & Amelia & 80 \\
\hline 2 & Ani Aprilia & 80 \\
\hline 3 & Asep Saepul Rohman & 68 \\
\hline 4 & Astri Wulandari & 72 \\
\hline 5 & Bunga Rismayanti & 80 \\
\hline 6 & Darsih & 70 \\
\hline 7 & Dede Shepiyadi & 70 \\
\hline 8 & Fajar Salim & 70 \\
\hline 9 & Febrian Reihan Falerian & 72 \\
\hline 10 & Indra Ar Maulana & 66 \\
\hline 11 & Kartika Putri & 78 \\
\hline 12 & Lelasari & 74 \\
\hline 13 & Lilis Marwati & 81 \\
\hline 14 & Maya Apriliani & 82 \\
\hline 15 & Maya Ismayanti & 80 \\
\hline 16 & Mira Rahayu & 74 \\
\hline 17 & Mohamad Irpan Maulana & 70 \\
\hline 18 & Muh Jaini Ikhsan & 72 \\
\hline 19 & Muhamad Ardiansyah & 70 \\
\hline 20 & Muhamad Haikal Zein & 72 \\
\hline 21 & Muhamad Mansur Habibi & 70 \\
\hline 22 & Muhamad Pebri & 70 \\
\hline 23 & Muhamad Rian Tiarno & 68 \\
\hline 24 & Noviyatul Salwa & 80 \\
\hline 25 & Putri Nadila Ramadhani & 80 \\
\hline 26 & Putri Solehatul Badriah & 80 \\
\hline 27 & Ratih Nurmalasari & 80 \\
\hline 28 & Rendi Maulana & 68 \\
\hline 29 & Rendi Surya Arwansyah & 70 \\
\hline 30 & Rico Dharma Rahayu & 70 \\
\hline 31 & Riki Purnama & 70 \\
\hline 32 & Riza Puadi & 66 \\
\hline & & \\
\hline
\end{tabular}




\begin{tabular}{lll}
\hline 33 & Rudi Julian & 70 \\
\hline 34 & Ryan Rahmat Hidayat & 68 \\
\hline 35 & Saepul Mahri & 68 \\
\hline 36 & Selawati & 80 \\
\hline 37 & Shifa Sakinah & 80 \\
\hline 38 & Suresih & 78 \\
\hline 39 & Wahyu & 70 \\
\hline 40 & Yanti Rahmawati & 74 \\
\hline
\end{tabular}

\begin{tabular}{ccc}
\hline \multirow{2}{*}{ Kriteria } & \multicolumn{2}{c}{ Nilai Prasiklus } \\
\cline { 2 - 3 } & Jumlah & $\%$ \\
\hline Tuntas & 16 & 35 \\
\hline Belum Tuntas & 24 & 65 \\
\hline Rata-rata & \multicolumn{2}{c}{73,53} \\
\hline
\end{tabular}

Pelaksanaan tindakan siklus I dilaksanakan dua kali pertemuan dengan waktu 3 jam pelajaran. Pada pertemuan pertama dilaksanakan pada hari Senin, 16 April 2018 dengan alokasi waktu 3 x 35 menit. Pelaksanaan penelitian ini adalah guru.

Tabel 2.Nilai Hasil Belajar Siklus I

\begin{tabular}{clc}
\hline No & \multicolumn{1}{c}{ Nama } & Nilai \\
\hline 1 & Amelia & 81 \\
\hline 2 & Ani Aprilia & 81 \\
\hline 3 & Asep Saepul Rohman & 72 \\
\hline 4 & Astri Wulandari & 73 \\
\hline 5 & Bunga Rismayanti & 81 \\
\hline 6 & Darsih & 72 \\
\hline 7 & Dede Shepiyadi & 72 \\
\hline 8 & Fajar Salim & 70 \\
\hline 9 & Febrian Reihan Falerian & 72 \\
\hline 10 & Indra Ar Maulana & 68 \\
\hline 11 & Kartika Putri & 80 \\
\hline 12 & Lelasari & 78 \\
\hline 13 & Lilis Marwati & 81 \\
\hline 14 & Maya Apriliani & 81 \\
\hline 15 & Maya Ismayanti & 81 \\
\hline 16 & Mira Rahayu & 78 \\
\hline 17 & Mohamad Irpan Maulana & 72 \\
\hline 18 & Muh Jaini Ikhsan & 72 \\
\hline 19 & Muhamad Ardiansyah & 72 \\
\hline 20 & Muhamad Haikal Zein & 72 \\
\hline 21 & Muhamad Mansur Habibi & 72 \\
\hline 22 & Muhamad Pebri & 72 \\
\hline 23 & Muhamad Rian Tiarno & 70 \\
\hline 24 & Noviyatul Salwa & 81 \\
\hline 25 & Putri Nadila Ramadhani & 81 \\
\hline & &
\end{tabular}

\begin{tabular}{lll}
\hline 26 & Putri Solehatul Badriah & 81 \\
\hline 27 & Ratih Nurmalasari & 80 \\
\hline 28 & Rendi Maulana & 70 \\
\hline 29 & Rendi Surya Arwansyah & 70 \\
\hline 30 & Rico Dharma Rahayu & 70 \\
\hline 31 & Riki Purnama & 70 \\
\hline 32 & Riza Puadi & 70 \\
\hline 33 & Rudi Julian & 75 \\
\hline 34 & Ryan Rahmat Hidayat & 70 \\
\hline 35 & Saepul Mahri & 70 \\
\hline 36 & Selawati & 81 \\
\hline 37 & Shifa Sakinah & 81 \\
\hline 38 & Suresih & 79 \\
\hline 39 & Wahyu & 71 \\
\hline 40 & Yanti Rahmawati & 76 \\
\hline
\end{tabular}

\begin{tabular}{ccc}
\hline \multirow{2}{*}{ Kriteria } & \multicolumn{2}{c}{ Nilai siklus 1} \\
\cline { 2 - 3 } & Jumlah & $\%$ \\
\hline Tuntas & 18 & 45 \\
\hline Belum Tuntas & 22 & 55 \\
\hline Rata-rata & \multicolumn{2}{c}{74,98} \\
\hline
\end{tabular}

Dari hasil belajar tersebut dapat dilihat peserta didik yang tuntas sebanyak 18 peserta didik sebesar $45 \%$ dan yang belum tuntas sebanyak 22 peserta didik atau sebesar $55 \%$ dengan rata-rata sebesar 74,98. Dari data tersebut dapat disimpulkan bahwa hasil belajar PPKn peserta didik kelas VIII E yaitu masih rendah dan belum mencapai Kriteria Ketuntasan Minimal (KKM)

Tabel 3. Perbandingan Nilai Pra Siklus dan Siklus I

\begin{tabular}{ccccc}
\hline \multirow{2}{*}{ Kriteria } & \multicolumn{2}{c}{$\begin{array}{c}\text { Nilai Pra } \\
\text { Siklus }\end{array}$} & \multicolumn{2}{c}{$\begin{array}{c}\text { Nilai siklus } \\
\end{array}$} \\
\cline { 2 - 5 } & Jumlah & $\%$ & Jumlah & $\%$ \\
\hline Tuntas & 14 & 35 & 18 & 45 \\
\hline $\begin{array}{c}\text { Belum } \\
\text { Tuntas }\end{array}$ & 26 & 64 & 22 & 55 \\
\hline $\begin{array}{c}\text { Rata- } \\
\text { rata }\end{array}$ & 73,53 & & 74,98 & \\
\hline
\end{tabular}

Dari tabel di atas dapat di lihat bahwa terjadi peningkatan dari nilai pra siklus ke siklus I. Peserta didik yang tuntas pada pra siklus sebanyak 14 peserta didik atau sebesar $35 \%$ menjadi 18 peserta didik atau sebesar $45 \%$ pada siklus I. peserta didik yang belum tuntas pada pra siklus sebanyak 26 peserta didik atau sebesar $64 \%$ menjadi 22 peserta didik atau sebesar 55 
\% pada siklus I, sedangkan nilai rata-rata pada pra siklus 73,53 menjadi 74,98 pada siklus I.

Pada pertemuan kedua dilaksanakan pada hari Senin, 14 Mei 2018 dengan alokasi waktu 3 x 35 menit.

Tabel 4. Nilai Hasil Belajar Siklus II

\begin{tabular}{clc}
\hline No & \multicolumn{1}{c}{ Nama } & Nilai \\
\hline 1 & Amelia & 85 \\
\hline 2 & Ani Aprilia & 81 \\
\hline 3 & Asep Saepul Rohman & 76 \\
\hline 4 & Astri Wulandari & 77 \\
\hline 5 & Bunga Rismayanti & 85 \\
\hline 6 & Darsih & 78 \\
\hline 7 & Dede Shepiyadi & 78 \\
\hline 8 & Fajar Salim & 73 \\
\hline 9 & Febrian Reihan Falerian & 78 \\
\hline 10 & Indra Ar Maulana & 75 \\
\hline 11 & Kartika Putri & 84 \\
\hline 12 & Lelasari & 83 \\
\hline 13 & Lilis Marwati & 85 \\
\hline 14 & Maya Apriliani & 85 \\
\hline 15 & Maya Ismayanti & 85 \\
\hline 16 & Mira Rahayu & 83 \\
\hline 17 & Mohamad Irpan Maulana & 77 \\
\hline 18 & Muh Jaini Ikhsan & 78 \\
\hline 19 & Muhamad Ardiansyah & 78 \\
\hline 20 & Muhamad Haikal Zein & 78 \\
\hline 21 & Muhamad Mansur Habibi & 80 \\
\hline 22 & Muhamad Pebri & 80 \\
\hline 23 & Muhamad Rian Tiarno & 76 \\
\hline 24 & Noviyatul Salwa & 84 \\
\hline 25 & Putri Nadila Ramadhani & 82 \\
\hline & & \\
\hline
\end{tabular}

Tabel 5. Perbandingan Hasil Belajar Nilai Pra siklus, Siklus I dan Siklus II

\begin{tabular}{ccccccc}
\hline \multirow{2}{*}{ Kriteria } & \multicolumn{2}{c}{ Nilai Pra siklus } & \multicolumn{2}{c}{ Nilai Siklus 1 } & \multicolumn{2}{c}{ Nilai Siklus 2 } \\
\cline { 2 - 7 } & Jumlah & $\%$ & Jumlah & $\%$ & Jumlah & $\%$ \\
\hline Tuntas & 14 & 35 & 18 & 45 & 39 & 97,5 \\
\hline Belum Tuntas & 26 & 55 & 22 & 65 & 1 & 2,5 \\
\hline Rata-rata & 73,53 & 74,98 & \multicolumn{2}{c}{80,03} \\
\hline
\end{tabular}

Dari tabel diatas dapat dilihat bahwa nilai hasil belajar peserta didik meningkat dari nilai pra siklus ke siklus I dan siklus II. Peserta didik yang tuntas pada nilai pra siklus sebanyak 14 peserta didik atau sebesar $35 \%$ menjadi 18 peserta didik atau sebesar $45 \%$ pada siklus I dan mencapai 39 peserta didik atau sebesar 97,5\% pada siklus II. Peserta didik yang belum tuntas

\begin{tabular}{lll}
\hline 26 & Putri Solehatul Badriah & 84 \\
\hline 27 & Ratih Nurmalasari & 85 \\
\hline 28 & Rendi Maulana & 78 \\
\hline 29 & Rendi Surya Arwansyah & 80 \\
\hline 30 & Rico Dharma Rahayu & 78 \\
\hline 31 & Riki Purnama & 76 \\
\hline 32 & Riza Puadi & 76 \\
\hline 33 & Rudi Julian & 80 \\
\hline 34 & Ryan Rahmat Hidayat & 78 \\
\hline 35 & Saepul Mahri & 76 \\
\hline 36 & Selawati & 84 \\
\hline 37 & Shifa Sakinah & 84 \\
\hline 38 & Suresih & 82 \\
\hline 39 & Wahyu & 76 \\
\hline 40 & Yanti Rahmawati & 80 \\
\hline
\end{tabular}

\begin{tabular}{ccc}
\hline \multirow{2}{*}{ Kriteria } & \multicolumn{2}{l}{ Nilai siklus II } \\
\cline { 2 - 3 } & Jumlah & $\%$ \\
\hline Tuntas & 39 & 97,5 \\
\hline Belum Tuntas & 1 & 2,5 \\
\hline Rata-rata & \multicolumn{2}{c}{80,03} \\
\hline
\end{tabular}

Dari data tersebut dapat dilihat bahwa peserta didik yang tuntas sebanyak 39 peserta didik atau sebesar $97,25 \%$ peserta didik yang belum tuntas sebanyak 1 peserta didik atau sebesar 2,50\% dengan nilai rata-rata 80,03. Dari data tersebut dapat disimpulkan bahwa hasil belajar PPKn peserta didik kelas VIII E pada siklus II sudah mengalami peningkatan dari nilai rata-rata pra siklus dan siklus I. peningkatan nilai rata-rata kelas pada siklus II sudah sesuai dengan kriteria keberhasilan yang ingin dicapai dalam penelitian ini.

pada nilai pra siklus sebanyak 26 peserta didik atau sebesar $55 \%$ menjadi 22 peserta didik atau $65 \%$ pada siklus I dan mencapai 1 peserta didik atau sebesar 2,5\% pada siklus II. Sedangkan nilai rata-rata pada nilai pra siklus sebesar 73,53 menjadi 74,98 pada siklus I dan mencapai 80,03 pada siklus II.

Pembahasan 
Model pembelajaran problem solving adalah cara penyajian bahan pelajaran dengan menjadikan masalah sebagai titik tolak pembahasan untuk dianalisis dalam usaha mencari pemecahan/jawaban oleh peserta didik (Mbulu, 2001, p. 52) Penyelesaian masalah menurut Johnson dan Johnson dalam Thobrani dan Musthofa dilakukan melalui kelompok. (Musthofa \& Thobrani, 2011). Dengan demikian dapat disimpulkan bahwa model pembelajaran problem solving adalah suatu metode yang merangsang peserta didik agar berfikir kritis, mampu menganalisa suatu persoalan sehingga sampai menemukan pemecahannya. Oleh karena itu, metode problem solving ini merupakan metode yang dapat membantu peserta didik untuk dapat membedakan masalah, untuk mencari alternatif pemecahan masalah yang tepat dan membantu peserta didik untuk membuat, memberikan dan mengambil keputusan dilihat dari hasil pengamatan ataupun observasi yang telah peneliti lakukan pada siklus I dan siklus II dapat diketahui tingkat aktivitas belajar peserta didik mengalami perubahan. Suasana kelas lebih baik dari sebelumnya., aktivitas peserta didik mengalami kemajuan terlihat dari semakin banyaknya peserta didik yang turut aktif dalam proses pembelajaran.

Model pembelajaran problem solving ini dilaksanakan di kelas VIII E SMP Negeri I Pabuaran Subang yang berjumlah 40 siswa. Pembelajaran telah dilaksanakan sesuai tahapan pelaksanaan yaitu perencanaan, pelaksanaan tindakan, observasi dan refleksi. Penelitian yang dilakukan ini memfokuskan pada pembelajaran PPKn dengan menggunakan model problem solving sehingga dapat meningkatkan hasil belajar siswa. Materi pembahasan yaitu tentang Semangat dan komitmen kebangsaan untuk memperkuat NKRI.

Pada Siklus I hasil belajar belum mencapai KKM, dikarenakan sebagian siswa masih belum berpartisipasi pada kerja kelompok, sebagian siswa belum bertanggungjawab pada kerja kelompok, siswa masih belum aktif bertanya dan menjawab pertanyaan, waktu yang diberikan oleh guru untuk melakukan diskusi, presentasi dan evaluasi terlalu singkat. Sehingga langkah selanjutnya peneliti dan guru menyusun rencana perbaikan pada siklus II, adapun perbaikan pada siklus II ini berpedoman pada hasil refleksi pada siklus I. Sehingga pada pertemuan pertama guru kembali membentuk kelompok. Hal ini penting dilakukan untuk membuat siswa terbiasa bekerja kelompok dan mau bekerja sama dengan siswa lain, setiap siswa dalam kelompok diberi soal wajib harus dikerjakan sehingga siswa akan berpartisipasi dalam kelompok, peneliti dan guru

menentukan waktu pelaksanaan tindakan siklus II yaitu dengan mengubah presentasi kelompok. Pertemuan pertama lima kelompok yang presentasi dan dilanjutkan dengan penjelasan guru. Tiga kelompok berikutnya presentasi pada pertemuan kedua. Pada observasi terhadap guru dalam melaksanakan penerapan strategi problem solving menunjukkan bahwa guru telah menerapkan pembelajaran sesuai dengan langkah-langkah problem solving. Dengan menggunakan model problem solving dalam pemebelajaran PPKn selama 2 siklus telah menunjukkan peningkatan hasil belajar PPKn di kelas VII E SMP Negeri I Pabuaran Subang

Ini dibuktikan dengan adanya peningkatan hasil belajar siswa dalam pembelajaran siklus I ke siklus II. Hal diatas dapat dilihat dari peningkatan hasil belajar siswa yaitu nilai ratatrata kelas pada nilai pra siklus sebesar 73,53. Kemudian pada siklus I menjadi 74,98 dan pada siklus II menjadi 80,03 . Jumlah siswa mampu mencapai KKM 75 pada nilai pra siklus ada 14 siswa, pada siklus I ada 18 siswa, dan pada siklus II ada 39 siswa. Berdasarkan hasil observasi pada nilai pra siklus siswa masih kurang atau masih rendah hal ini di karenakan sebagian besar siswa belum menguasai atau memahami materi pembelajaran yang ada. Sehingga siklus I hasil belajar siswa mulai terlihat meskipun yang terlibat aktif dalam mengerjakan diskusi kelompok hanya beberapa siswa. Namun pada siklus II guru merencanakan lebih memotivasi agar siswa yang belum berani, belum aktif, dan memberikan kesempatan untuk bertanya dan menjawab pertanyaan yang diberikan guru. Sehingga hasil belajar siswa lebih meningkat. 
Berdasarkan hasil yang telah diperoleh dari siklus I sampai siklus II dapat disimpulkan bahwa dengan menggunakan model problem solving dapat meningkatkan hasil belajar PPKn siswa kelas VIII E SMP Negeri I Pabuaran Subang.

\section{KESIMPULAN.}

Berdasarkan hasil penelitian dan pembahasan yang telah diuraikan pada bab sebelumnya, maka dapat diambil suatu simpulan yaitu penggunaan metode problem solving dapat meningkatkan hasil belajar PPKn siswa kelas VIII E SMP Negeri 1 Pabuaran Subang. Hal ini dapat dilihat dari hasil belajar siswa pada siklus I dengan rata-rata sebesar 74,98 dan ketuntasan individual sebanyak 18 orang. Pada siklus II rata-rata hasil belajar siswa sebesar 80,03 dan ketuntasan individu sebanyak 39 orang. Jadi hasil belajar siswa dari siklus I sampai dengan siklus II mengalami peningkatan. Adapun kendala yang dihadapi dalam upaya meningkatkan hasil belajar siswa kelas VIII E SMP Negeri 1 Pabuaran Subang adalah masih melekatnya kebiasaan siswa menerima pelajaran dari guru dengan metode ceramah, dan mengerjakan tugas-tugas yang berpatokan pada Lembar Kerja Siswa/Modul.

\section{DAFTAR PUSTAKA}

Kemdikbud. (2014). Modul Pelatihan Kurikulum 2013. Jakarta: Puskur Kemdikbud.

Kojong, T. K. (2017). Peningkatan Hasil Belajar PKn Melalui Penerapan Model Problem Solving. Jurnal Pendidikan Guru Sekolah Dasar.

Mbulu, J. (2001). Pengajaran Individual Pendekatan Metode Dan Media Pedoman Mengajar Bagi Guru Dan Calon Guru. Malang: Yayasan Elang Emas.

Musthofa, A., \& Thobrani, M. (2011). Belajar dan Pembelajaran Pengembangan Wacana dan Praktik Pembelajaran dalam Pembangunan Nasional. Jogjakarta: Ar-Ruzz Media.

Putra, M. D., Putra, I. M., \& Suara, I. M. (2014). Model Pembelajaran Problem Solving Berpengaruh Terhadap Hasil Belajar PKn Kelas V SD Gugus Srikandi Denpasar. e-
Journal Mimbar PGSD Universitas Pendidikan Ganesha.

Susanto, A. (2013). Teori Belajar ES Pembelajaran di Sekolah Dasar. Jakarta: Penada Media Grup. 